\title{
Estimation of Failure Frequency for Type I and II High Level Waste Tanks
}

\author{
K. H. Subramanian
}

Savannah River Technology Center

Strategic Materials Technology Department

Materials Technology Section

Publication Date: March 2001

DOES NOT CONTAIN

UNCLASSIFIED CONTROLLED

NUCLEAR INFORMATION

$A D C \&$

Official

Date: $3-13-01$

\section{Westinghouse Savannah River Company}

Savannah River Site

\section{Aiken, SC 29808}

This document was prepared in connection with work done under Contract No. DE-AC09-96SR18500 with the U. S. Department of Energy 
This document was prepared in conjunction with work accomplished under Contract No.

DE-AC09-96SR18500 with the U.S. Department of Energy.

\section{DISCLAIMER}

This report was prepared as an account of work sponsored by an agency of the United States Government. Neither the United States Government nor any agency thereof, nor any of their employees, makes any warranty, express or implied, or assumes any legal liability or responsibility for the accuracy, completeness, or usefulness of any information, apparatus, product or process disclosed, or represents that its use would not infringe privately owned rights. Reference herein to any specific commercial product, process or service by trade name, trademark, manufacturer, or otherwise does not necessarily constitute or imply its endorsement, recommendation, or favoring by the United States Government or any agency

thereof. The views and opinions of authors expressed herein do not necessarily state or reflect those of the United States Government or any agency thereof.

This report has been reproduced directly from the best available copy.

Available for sale to the public, in paper, from: U.S. Department of Commerce, National Technical Information Service, 5285 Port Royal Road, Springfield, VA 22161, phone: (800)

553-6847, fax: (703) 605-6900, email: orders@ntis.fedworld.gov online ordering: http://www.ntis.gov/ordering.htm

Available electronically at http://www.doe.gov/bridge

Available for a processing fee to U.S. Department of Energy and its contractors, in paper, from: U.S. Department of Energy, Office of Scientific and Technical Information, P.O. Box 62, Oak Ridge, TN 37831-0062, phone: (865 ) 576-8401, fax: (865) 576-5728, email: reports@ adonis.osti.gov 
DOCUMENT: WSRC-TR-2001-00022

TITLE: $\quad$ Estimation of Failure Frequency for Type I and Type II High Level Waste Tanks

\section{APPROVALS}

Kattut hlasin Date: 3/12/01

K. H. Subramanian, Author

Materials Applications \& Process Technology Group

Materials Technology Section

Q. 0 . Q $3 / 12 / 01$

A. J. Dunc;n, Technical Reviewer

Materials Applications \& Process Technology Group

Materials Technology Section

Sohn Morkus pertatecon to stephen HAOH Date: 3-13-OI

Westinghouse Safety Management Solutions
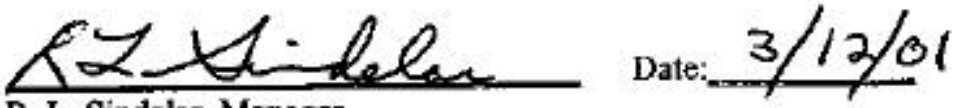

R. L. Sindelar, Manager

Materials Applications \& Process Technology Group

Materials Technology Section

Buna 1. theorne Date:3/12/01

B. J. Wiersma, Tank Life Management Program

Materials Performance \& Corrosion Technology Group

Materials Technology Section

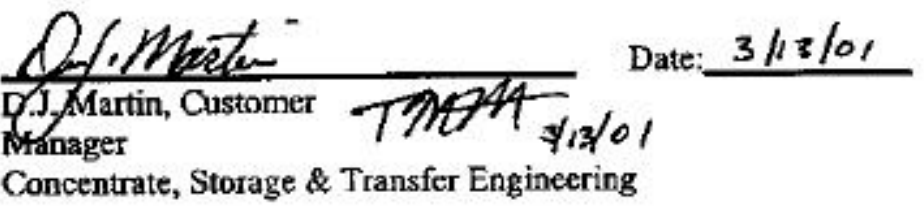

\section{H). CQR \\ Date: $3 / 12 / 01$}

G. T. Chandler, Manager

Materials Performance \& Corrosion Technology Group

Materials Technology Section

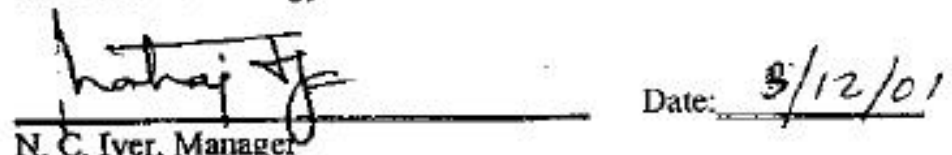

N.C. Iyer, Manager

Materials Technology Section

Savannah River Technology Center 
(THIS PAGE LEFT INTENTIONALLY BLANK) 


\section{TABLE OF CONTENTS}

TABLE OF CONTENTS III

LIST OF TABLES ............................................................................................................................................................... IV

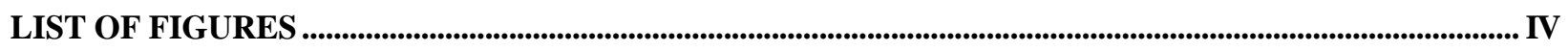

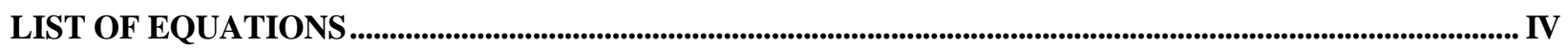

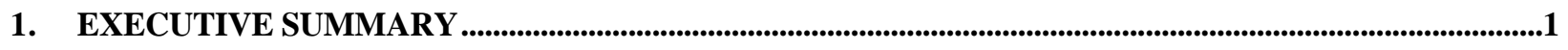

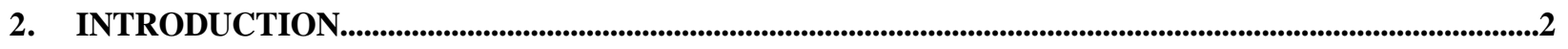

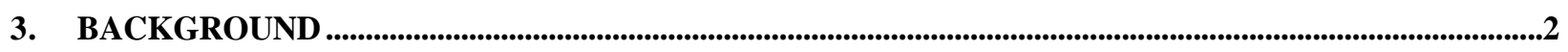

4. METHODOLOGY FOR FAILURE FREQUENCY ESTIMATION ...................................................................3

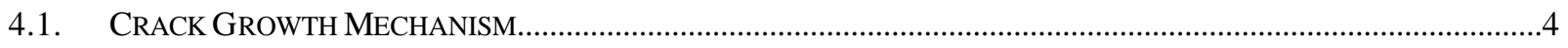

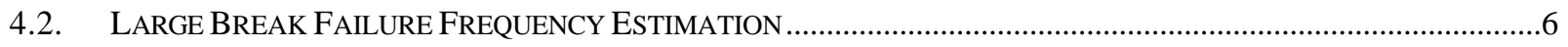

5. ASSOCIATED PROBAB ILITIES..................................................................................................................................

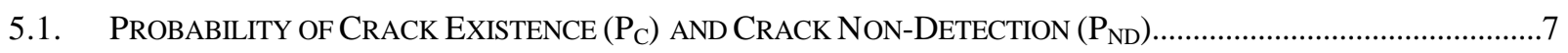

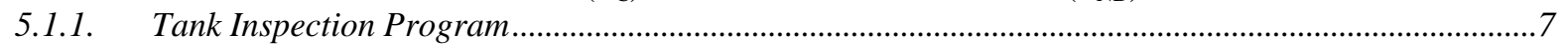

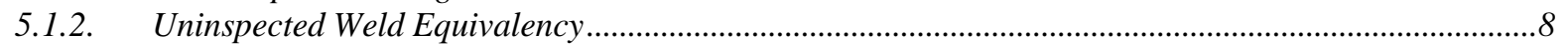

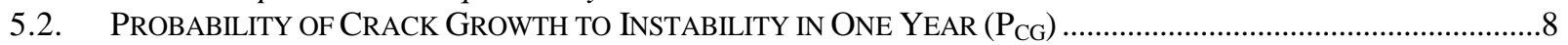

5.2.1. Crack Growth Rate due to Nitrate-SCC ……...............................................................................

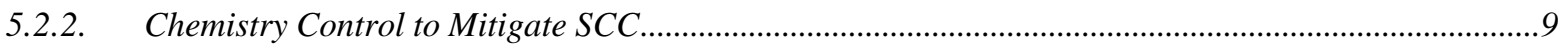

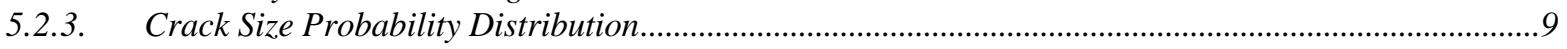

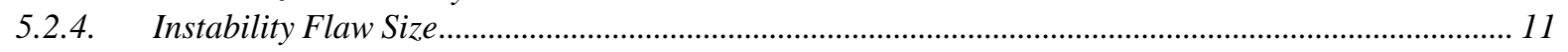

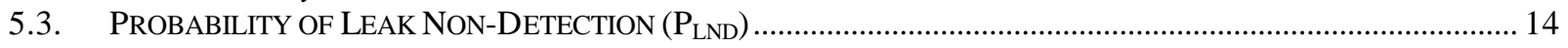

5.3.1. Leakage Characterization Including Leak-Before-Break Methodology ............................................. 14

5.3.2. Conductivity Probe Leak Detection Systems .......................................................................... 15

5.3.3. Probability of Leak Non-Detection $\left(P_{L N D}\right)$ Calculation................................................................ 17

6. ESTIMATION OF LARGE BREAK FREQUENCY UNDER NORMAL OPERATION............................. 18

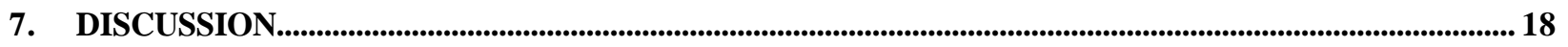

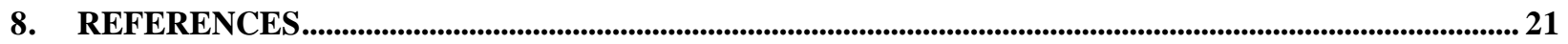




\section{LIST OF TABLES}

TABLE 1: Allowable TANK FILl Limits FOR TyPE I AND TyPe II TANKS. (REPRODUCED FROM REFERENCES 14 AND $15)^{*}$

TABLE 2: PARAMETERS AND CONDITIONS USED FOR PROBABILISTIC RISK METHODOLOGY

\section{LIST OF FIGURES}

FIGURE 1: TYPE 1 HIGH LEVEL WASTE TANK SCHEMATIC........................................................................................

FIGURE 2: TYPE II HIGH LEVEL WASTE TANK SCHEMATIC. ...............................................................................

FigURE 3: RESIDUAL STRESS DisTRIBUTION AROUND SingLE BUTT WELDS. (REPRODUCED FROM REFERENCE 4) .......5

Figure 4: STRESS INTENSITY FACTORS DUE TO RESIDUAL STRESS FOR VERTICAL CRACKS. (REPRODUCED FROM

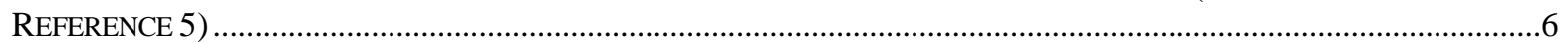

FiguRE 5: PROBABILITY DENSITY FUNCTION OF TANK 16 CRACK LENGTH DATA AND ADJUSTED DATA TO

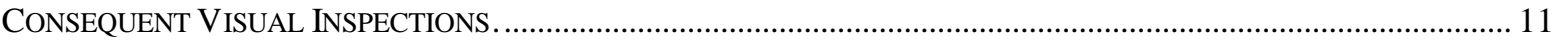

Figure 6: CUMUlative DenSiTy FunCTION OF TANK 16 CRACK LENGTH DATA AND ADJUSTED Data to CONSEQUENT VISUAL INSPECTIONS

FigURE 7: FLAW INSTABILITY LENGTHS ( $\mathrm{SF}=1$ ) AND FILL LIMITS ( $\mathrm{SF}=2$ ) FOR TYPE I TANKS UNDER NORMAL OPERATING CONDITIONS. (REPRODUCED FROM REFERENCE 13)-..

FIGURE 8: EXPONENTIAL REGRESSION ANALYSIS OF EFFECT OF SPECIFIC GRAVITY ON INSTABILITY FLAW SIZE OF

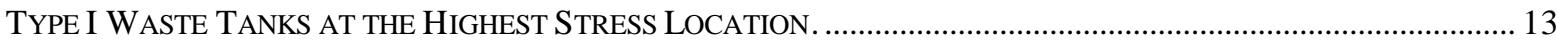

FiguRE 9: ACTIVE DUAL REDUNDANT CONDUCTIVITY PROBE SYSTEM...................................................................... 17

FigURE 10: SENSITIVITY OF FAILURE FREQUENCY OF LARGE BREAK FAILURE TO INSTABILITY FLAW SIZE. ............... 19

\section{LIST OF EOUATIONS}

EQUATION 1: ANNUAL FAILURE FREQUENCY OF LARGE BREAK FAILURE......................................................................6

EQUATION 2: PROBABILITY OF LARGE BREAK FAILURE DUE TO CRACK INITIATING IN UNINSPECTED WELD. ................7

EQUATION 3: PROBABILITY OF LARGE BREAK FAILURE DUE TO CRACK INITIATING IN INSPECTED WELD........................7

EQUATION 4: PROBABILITY OF LARGE BREAK FAILURE EQUIVALENT ONLY TO UNINSPECTED WELD ............................8

EQUATION 5: LOGNORMAL DISTRIBUTION ……….................................................................................... 10

EQUATION 6: CoNDUCTIVITY PROBE LEAK DETECTION FAILURE. ........................................................................... 17

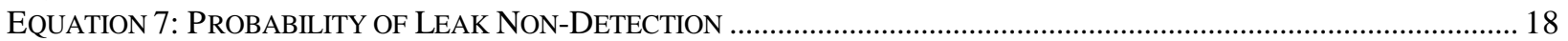




\section{EXECUTIVE SUMMARY}

The failure frequency of Type I and Type II High Level Waste tanks was calculated. The degradation mechanism that could lead to large break failure and the credits taken for steps taken to prevent large break failure were considered. The annual probability of failure or failure frequency of the the Type I and Type II High Level Waste Tanks was estimated to be $1 \times 10^{-8}$ large breaks/year (per tank).

The following were considered for failure frequency calculations:

\begin{tabular}{|c|c|}
\hline Large Break Failure & $\begin{array}{l}\text { A large break failure is defined to occur when a flaw, undetected or } \\
\text { detected, grows to the point of instability, and causes rapid, unstable } \\
\text { unzipping to open the structure. }\end{array}$ \\
\hline Degradation Mechanism & $\begin{array}{l}\text { Nitrate stress corrosion cracking, initiating in the residual stress field } \\
\text { of welds, is the primary mechanism that can cause large break failure. } \\
\text { The crack growth rate was determined to be } 2.5 \mathrm{in} / \mathrm{yr} \text { in laboratory } \\
\text { tests. }\end{array}$ \\
\hline $\begin{array}{l}\text { Leading to large break } \\
\text { failure }\end{array}$ & $\begin{array}{l}\text { The instability flaw size used for the failure frequency calculation } \\
\text { was } 18 \text { in., which was determined at } 100 \% \text { fill of Type I tanks at a } \\
\text { liquid specific gravity of } 1.7 \text {. The results for other specific gravities } \\
\text { are provided. }\end{array}$ \\
\hline $\begin{array}{c}\text { To prevent large break } \\
\text { failure }\end{array}$ & $\begin{array}{l}\text { Visual Inspections: No credit for visual crack detection is assumed in } \\
\text { the failure frequency estimation since regions of the tanks are } \\
\text { inaccessible. } \\
\text { Leak Detection System: The annulus of each of the Type I and II } \\
\text { waste tanks are installed with at least two single-point conductivity } \\
\text { probes for leak detection. These probes are safety class } \\
\text { instrumentation and are alarmed. } \\
\text { The leak-before-break capability is applied in detecting flaws well } \\
\text { before instability. } \\
\text { Crack Growth Mitigation: Solution chemistry control is in place to } \\
\text { prevent the initiation and growth of stress corrosion cracking. } \\
\text { There are controls in place to quickly develop an effective response } \\
\text { plan to leaking cracks. This response plan could include waste } \\
\text { transfer below a point to stop leaking and also additional surveillance. }\end{array}$ \\
\hline
\end{tabular}

The failure frequency is a combination of the probability of four factors: (1) $\mathrm{P}_{\mathrm{c}}$, likelihood of the existence of a through-wall crack at the highest stress location in tank, (2) $\mathrm{P}_{\mathrm{ND}}$, likelihood of non-detection of a through-wall crack, (3) $P_{C G}$, the crack size distribution with crack growth to instability in a given time period, (4) and $\mathrm{P}_{\mathrm{LND}}$, an estimation of the probability of "Leak Non-Detection" (LND) using conductivity probe system. 
The final failure frequency of Type I and Type II tanks, generically, was calculated to be $1 \mathrm{E}-8$ large breaks per year using the previously mentioned parameters. By definition, this is the probability of a large break failure within one year using the crack size distribution assumed to be the current configuration of the cracks of a Type I or Type II High Level Waste Tank.

\section{INTRODUCTION}

The High Level Waste Life Management Program contains activities to ensure the structural integrity of Type I and Type II high level waste tanks. This report, as part of the life management program, describes a methodology for the estimation of the direct large break failure frequency of a Type I or Type II tank. A direct failure frequency is defined as the probability of a large break failure per unit time (i.e., 1 year). For example, a large break failure by direct means could occur when a flaw, undetected or detected, grows to the point of instability, and causes rapid, unstable unzipping to open the structure.

A probabilistic methodology developed by Lawrence Livermore National Laboratory (LLNL) to estimate the pipe break probability or break frequency is adapted here for application to Type I and Type II waste tanks. LLNL developed a probabilistic fracture mechanics methodology for the assessment of double-ended guillotine break (DEGB) of a pipe from both direct and indirect causes. The DEGB probability assessment from direct causes considered the growth of as-fabricated surface flaws at welded joints, taking into account loads on the piping due to normal operating conditions and seismic events. Other factors, including the capability to detect pipe cracks and pipe leaks were also addressed in that previous work. ${ }^{1}$ The LLNL methodology is adopted to calculate a direct failure frequency of Type I and Type II high level waste tanks. Degradation mechanisms that could lead to large break failure of high level waste tanks are considered. Indirect causes of failure (e.g., failure of concrete vault causing failure of steel tank) are not addressed.

\section{BACKGROUND}

Type I and Type II waste tanks were made of ASTM Type A285-50T, Grade B steel. The material was melted in an open-hearth furnace, semi-killed, and the hot-rolled into plate. There are a total of 12 Type I tanks, and 4 Type II waste tanks.

Type I tanks (shown in Figure 1) have a capacity of 750,000 gallons, are 75 feet in diameter, and $24 \frac{1}{2}$ feet high. The primary tanks are a closed cylindrical tank with flat top and bottom constructed from $1 / 2$ in. thick steel plate. The top and bottom are joined to the cylindrical sidewall by curved knuckle plates. Type II tanks (shown in Figure 2) have a capacity of 1,030,000 gallons, are 85 feet in diameter, and 27 feet high. The primary container for Type II tanks consists of two concentric steel cylinders assembled with a flat bottom and flat top forming a doughnut. The top and bottom are joined to the outer cylinder by rings of curved knuckle plates. Neither Type I nor Type II waste tanks are stress relieved. Single-butt girth welds join each of the plates in both, Type I and Type II waste tanks. The tanks are constructed with a top weld to the top of the tank, middle welds between plates, and bottom welds to the bottom of the plate. A 5-foot high steel pan provides secondary containment for the tanks and a concrete vault encompassing the primary tank and the steel pan provides another barrier before waste can reach the ground. 


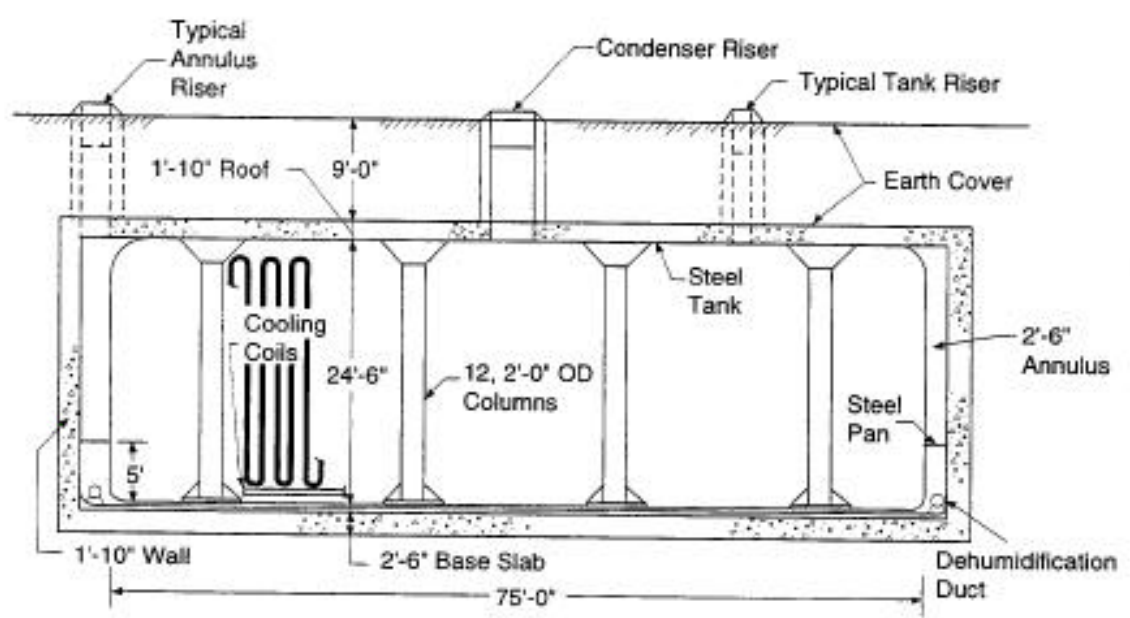

Figure 1: Type 1 High Level Waste Tank Schematic.

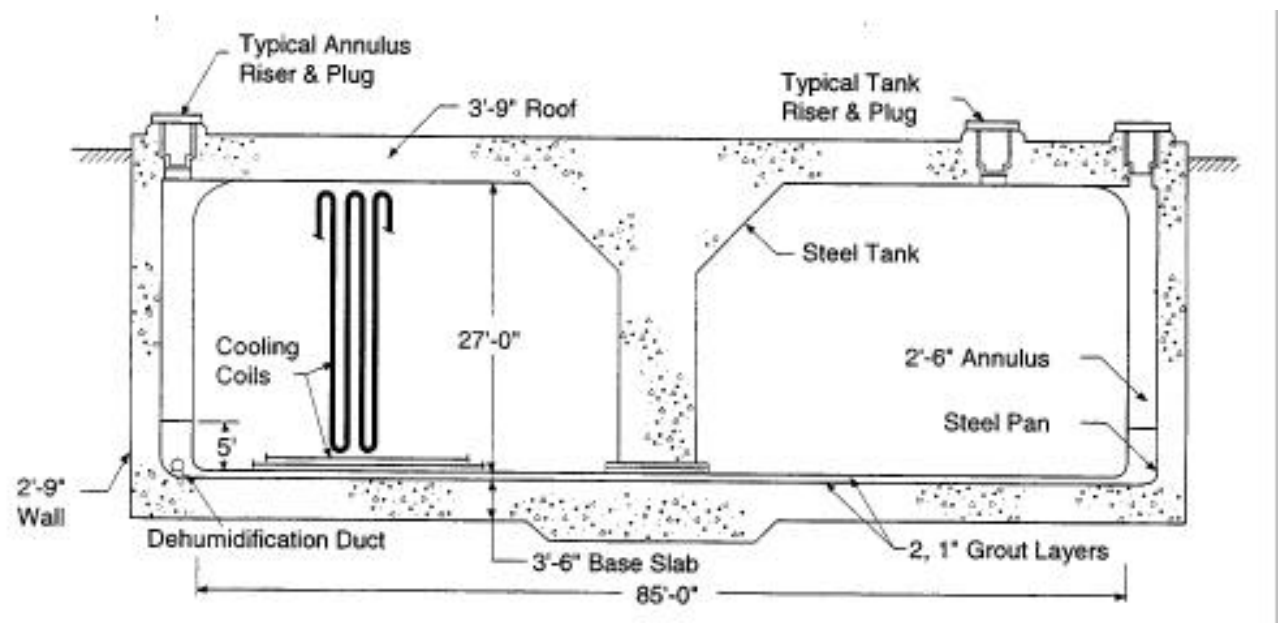

Figure 2: Type II High Level Waste Tank Schematic.

\section{METHODOLOGY FOR FAILURE FREQUENCY ESTIMATION}

The first step is to identify the failure mechanism that can lead to a large break failure. Waste tanks are subject to two primary degradation mechanisms. The first of which is localized corrosion (i.e., pitting) that is caused by nitrate ions which break down the protective oxide layer of steels. Pitting corrosion can lead to localized wall thinning, and in extreme cases, leaks. However, without the contribution of stress-corrosion cracking, pitting cannot lead to large break failure of the waste tanks. The second primary degradation mechanism is stress corrosion cracking which is also triggered by the presence of nitrate ions. The tank operating history has shown that this mechanism was active in Types I and II tanks, at least prior to chemistry control in the 1970's.

Stress corrosion cracks that initiated from single-butt girth welds and grew perpendicularly to the weld were considered. Only axial cracks were considered, and circumferential cracks were disregarded. Large break failure, for purposes of this study, is defined to be the unstable propagation of one such stress-corrosion crack through the tank to the 
point of instability. Crack growth not rapidly propagating to failure is termed "subcritical" crack growth. Cracks that are identified as "unstable" can propagate up to the speed of sound in the waste tank material. It is visualized that large break failure will comprise of unstable crack growth from top to bottom of Type I and II high level storage tanks, indicating "unzipping" failure. This type of failure occurs when a crack is able to traverse over girth welds, and continue vertically throughout the height of the tank. The result of the failure will be the spillage of all contained materials into the annular space, and the complete loss of primary containment. The primary degradation mechanism contributing to the probability of large break failure in Type I and II high level waste tanks is considered to be stress corrosion cracking.

Section 4.1 describes nitrate stress corrosion cracking. Section 4.2 describes the method used to estimate the failure frequency for nitrate SCC. A probability for each of the components that comprise the overall failure frequency is assigned. Credit is taken for inspections and leak detection systems in place. The inspections and leak detection systems are critical in detecting flaws to avoid a potential large break failure. The response plan to leak detection system alarms is considered effective to avoid large break failure in all cases.

\subsection{Crack Growth Mechanism}

Stress corrosion cracking was determined to be the principal degradation mechanism for the primary liner in Type I and II high level waste tanks. ${ }^{2,3}$ Stress-corrosion cracking is the formation of cracks in the presence of tensile stresses in a hostile environment. In addition, low carbon ferritic steels are commonly known to be susceptible to intergranular stress-corrosion cracking in nitrate solutions.

Specifically, cracks in waste tanks were initiated by exposure to a hot aqueous solution containing nitrates in the presence of a residual stress field due to girth welds. It is important to note that Type I and II high level waste tanks were not stress-relieved prior to installation. The residual stress field created as a consequence of solidified weld metal in the presence of surrounding cool base metal during welding provided the tensile stress necessary to initiate a stress corrosion crack. In addition, the residual stresses provided the crack driving force necessary for stress-corrosion cracking. Residual stresses may not strongly affect flaw stability. Under a high level of applied stress, the effect of residual stress is diminished, and net section yielding would control the failure. Crack that extend well beyond the residual stress field near the welds would also be less affected by these stresses considering flaw stability.

Previous visual and ultrasonic examinations of Type I and II waste tanks have determined that five Type I waste tanks and all four Type II waste tanks have developed through-wall cracks near the welds. This cracking has been attributed to stress-corrosion cracking. These cracks were self-plugged by salt deposition around the flaws.

The residual stress field around a single butt girth weld was done to assess the extent of influence of the residual stress field around the weld. The crack driving force which are the residual stresses around the weld HAZ, decrease with distance from the weld line. Therefore, the crack will theoretically be arrested outside of the residual stress field when the stress intensity created by the residual stress field falls below the stress intensity required to drive an intergranular stress-corrosion crack (KIGSCC). 
Analysts at Battelle Memorial Institute, Columbus performed thermomechanical calculations for WSRC to obtain the residual stress distributions for single butt welds. ${ }^{4}$ The inplane residual stress (parallel to butt weld) responsible for the growth of a vertical crack (perpendicular to the butt weld) was calculated to go to zero, as shown in Figure 3 at approximately $0.75 \mathrm{in}$. This residual stress provided the stress intensity necessary for subcritical (stable) crack growth due to stress corrosion. The threshold stress intensity factor of stress corrosion cracking $\left(\mathrm{K}_{\mathrm{Iscc}}\right)$ was previously determined in to be $32 \mathrm{ksi}-\mathrm{in}^{1 / 2}$. Therefore, it was determined that the maximum length of stress corrosion cracking due to the residual stress field created from a single butt girth weld is 1.5 inches. ${ }^{5}$ The stress intensity factor due to the residual stress for vertical cracks is shown in Figure 4.

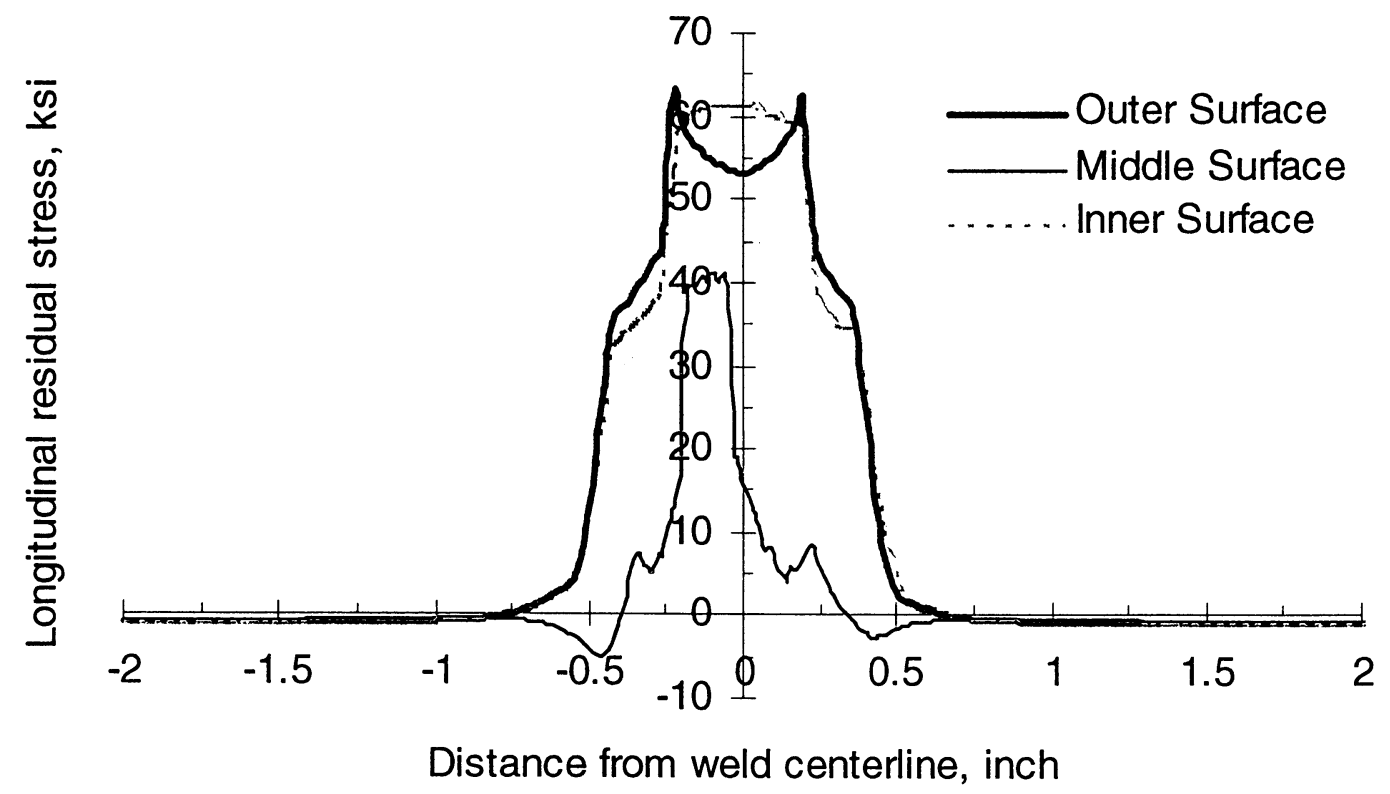

Figure 3: Residual Stress Distribution Around Single Butt Welds. (Reproduced from Reference 4) 


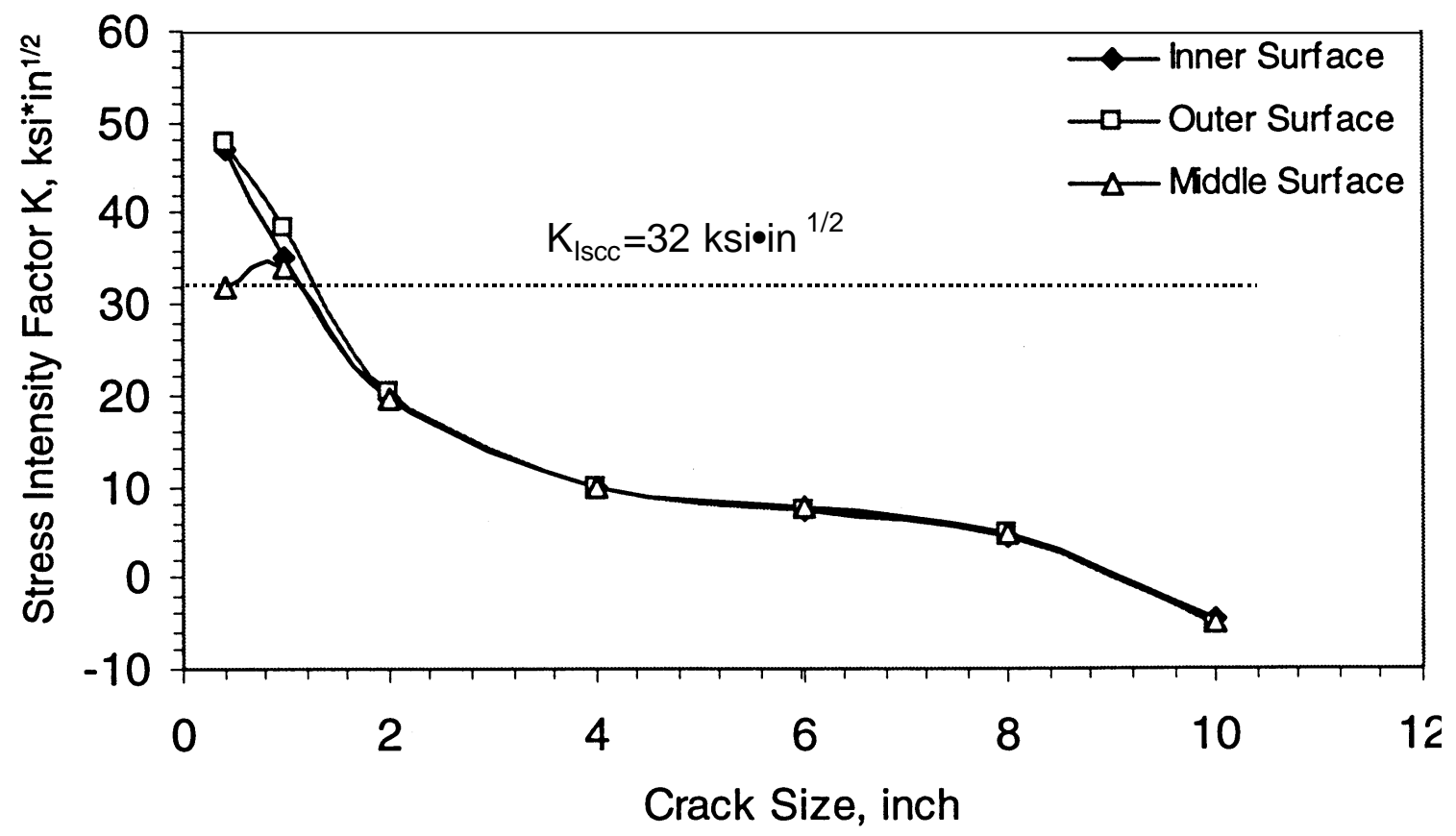

\section{Figure 4: Stress Intensity Factors due to Residual Stress for Vertical Cracks. (Reproduced from Reference 5)}

It is important to note that material that was stress-relieved, e.g., Type III high level waste tanks, have shown no evidence of cracking. This lends further validity to residual stress fields providing the primary tensile stress required for stress-corrosion cracking.

\subsection{Large Break Failure Frequency Estimation}

The annual frequency of large break failure is postulated to be comprised of two components, the probability of failure due to a stress corrosion crack originating in (1) an uninspected weld and (2) an inspected weld.

\section{Equation 1: Annual Failure Frequency of Large Break Failure.}

$$
\mathbf{P}_{\mathrm{FF}}=\mathbf{P}_{\mathrm{UIW}}+\mathbf{P}_{\mathrm{IW}}
$$

1. $\mathrm{P}_{\text {UIw }}=$ Probability of large break failure due to stress-corrosion crack originating in uninspected welds.

2. $\mathrm{P}_{\mathrm{IW}}=$ Probability of large break failure due to stress-corrosion crack originating in inspected welds.

The annual large break frequency units are large breaks per year or LB/year. The product of individual component probabilities yields the total annual large break frequency. For purposes of this study, only the probability of a stress-corrosion crack initiating and growing to cause a large break failure in one year was considered. The failure frequency calculated is valid 
only for a Type I and II high level waste tank with an assumed existing crack distribution. Failure frequency calculations for a specific cracked tank could be performed with tank-specific flaw information.

Each of probabilities ( $\mathrm{P}_{\mathrm{UIW}}$ and $\mathrm{P}_{\mathrm{IW}}$ ) that comprise the total failure frequency was determined to be a combination of four probabilities:

Equation 2: Probability of Large Break Failure due to Crack Initiating in Uninspected Weld.

$$
\mathbf{P}_{\mathrm{UIW}}=\mathbf{P}_{\mathrm{C}} \cdot \mathbf{P}_{\mathrm{ND}} \cdot \mathbf{P}_{\mathrm{CG}} \cdot \mathbf{P}_{\mathrm{LND}}
$$

Equation 3: Probability of Large Break Failure due to Crack Initiating in Inspected Weld.

$$
\mathbf{P}_{\mathrm{IW}}=\mathbf{P}_{\mathrm{C}} \cdot \mathbf{P}_{\mathrm{ND}} \cdot \mathbf{P}_{\mathrm{CG}} \cdot \mathbf{P}_{\mathrm{LND}}
$$

1. $\mathrm{P}_{\mathrm{c}}=$ Likelihood of the existence of a through-wall crack at the highest stress location in tank.

2. $\mathrm{P}_{\mathrm{ND}}=$ Likelihood of non-detection of a through-wall crack.

3. $\mathrm{P}_{\mathrm{CG}}=$ Provides crack size distribution with crack growth to instability in a given time period.

4. $\mathrm{P}_{\mathrm{LND}}=$ Estimates probability of "Leak Non-Detection" (LND) using the conductivity probe system.

\section{ASSOCIATED PROBABILITIES}

\subsection{Probability of Crack Existence $\left(P_{C}\right)$ and Crack Non-Detection $\left(P_{N D}\right)$}

The probability of crack existence $\left(\mathrm{P}_{\mathrm{c}}\right)$ assessed the likelihood of the initiation of a stress corrosion crack in the residual stress field of single butt girth weld. Stress corrosion cracking was determined to have taken place by intergranular crack growth driven by anodic dissolution which preferentially removed heavily stressed material by chemical means. Stress corrosion cracking has been determined to be the primary degradation mechanism, and is the only degradation mechanism considered for purposes of this calculation.

\subsubsection{Tank Inspection Program}

An in-service inspection plan that focuses on identification and characterization (i.e., size, location, etc.) of flaws in Type I and Type II waste tanks is an ongoing program. ${ }^{6}$ It has been developed to organize evaluations of the condition of high level waste tanks and associated structures, systems, and components. The inspection program is an integral part of the overall program designed to maintain confinement throughout the desired service life and to manage material aging through monitoring, inspection, and predictive testing. Monitoring and inspection provides early detection of degradation and information that can be used for degradation evaluation.

Inspection techniques utilize visual imagery and thickness measurements. The current inspection consists of direct photography that involves making detailed views of the tank walls and annular space. The limitations of the imaging technique is such that cracking that have led 
to leaks are easily detectable. However, cracking that has not led to leakages cannot be visualized. In addition, only $73 \%$ of the exterior wall of Tank 6 can be inspected. The remaining $27 \%$ of the exterior wall of Tank 6 is not currently accessible.

Historically, 5 of 12 Type I waste tanks were found to be cracked. Each of the 4 Type II tanks were found to be cracked. That indicated a statistical incidence probability of $9 / 16$ for the existence of a stress corrosion crack in these waste tanks, i.e., $P_{c}=9 / 16$. However, it was assumed that cracks exist in tank spaces inaccessible to visual imagery due to their existence in the accessible regions. It is also assumed that a stress corrosion crack initiating/growing in an uninspected region of the weld can grow to instability. Therefore, for purpose of this analysis, $\mathrm{P}_{\mathrm{c}}$ is assumed to be 1 . Consequently, the probability of non-detection of a through-wall crack by visual imagery was determined to be 1 , i.e., $\mathrm{P}_{\mathrm{ND}}=1$.

\subsubsection{Uninspected Weld Equivalency}

For purposes of this study, no partitioning of the failure frequency between uninspected and inspected welds is considered. The entire tank is assumed to be susceptible to stress corrosion cracking and assumed to be uninspected because of visual access limitations. Therefore, the probability of a large break failure is equivalent to the probability of failure of a stress corrosion crack initiating from an uninspected weld, as shown in Equation 4. As a result, there is no credit taken for possible remediatory action taken once a crack that does not leak, assumed to be a result of stress-corrosion cracking, is identified by visual inspection.

\section{Equation 4: Probability of Large Break Failure Equivalent Only to Uninspected Weld}

$$
\mathbf{P}_{\mathbf{F F}}=\mathbf{P}_{\text {UIW }}
$$

\subsection{Probability of Crack Growth to Instability in One Year $\left(P_{C G}\right)$}

This conditional probability assessed the likelihood of a crack leading to a large break as a time-dependent term (i.e., 1 year for an annual failure frequency). Calculation of the probability of crack growth to instability took into account the primary degradation mechanism (SCC) and the rate of SCC cracking, possible mitigation of SCC cracking through solution chemistry control, the crack size probability distribution, and the instability flaw size calculated using fracture mechanics methodologies. The crack size cumulative probability distribution was used to calculate the probability of crack growth beyond its instability point (leading to large break failure) in one year assuming SCC as the only and primary degradation mechanism.

\subsubsection{Crack Growth Rate due to Nitrate-SCC}

It was experimentally determined that the degradation rate due to stress corrosion cracking in a nitrate environment was 1.25 inches per year (ipy). ${ }^{7}$ This translates to a crack growth rate of 2.5 ipy in the waste tanks. The tests were done on wedge-opening loaded (WOL) specimens made of non-stress relieved carbon steel. The tests were done to determine the crack growth rate of a SCC crack due to a girth weld. Crack growth rates were calculated in an environment of uninhibited wastes with nitrate as the aggressive species. The environment was chosen to reflect service conditions of Type I and Type II waste tanks. 


\subsubsection{Chemistry Control to Mitigate SCC}

Controls on solution chemistry were instituted in the late 1970's to preclude the initiation and propagation of SCC in the waste tanks. Previous work established the condition for growth and inhibition of nitrate-induced SCC in carbon steel for application to waste tanks. ${ }^{8}$ It was found that sufficient concentrations of hydroxide and nitrite prevent or arrest nitrate SCC in waste tank steel, and these have been codified in the chemistry controls for the waste tanks.

The chemistry controls in the waste tanks are based upon previous experimentation. Laboratory tests have indicated that chemistry control arrests crack growth in the and prevents initiation of new cracks in the non-stress-relieved tanks. ${ }^{7}$ WOL specimen tests were utilized to characterize crack growth in nitrate solution. The WOL tests showed that in solutions that caused crack growth, the growth rate and $\mathrm{K}_{\mathrm{SCC}}$ were independent of bulk nitrate concentration. This indicated that solution chemistry at the crack tip controls crack growth. In addition, it was found that crack propagation depended only upon nitrite and hydroxide concentration and was independent of nitrate concentration and temperature. However, crack initiation was dependent upon all four variables.

\subsubsection{Crack Size Probability Distribution}

Numerous cracks have been found in Type I and Type II waste tanks during visual inspections. An analysis of cracks in an out-of-service tanks was performed and adjusted to reflect further visual examinations. The adjustment of the data was inherently conservative as the crack lengths assumed were outside of the residual stress field of the girth welds. As previously mentioned, the residual stress field provides the tensile stress necessary for a SCC only 1.5 inches in length.

The crack size distribution development is divided into two parts: (1) statistical analysis of the crack length data compiled on retired Tank 16 (Type II waste tank) and (2) development of a bounding estimate of flaw size distribution to fit consequent crack length data of in-service tanks and reference flaw size calculations. Tank 16, a Type II tank, was considered representative and bounding of all Type I and II waste tanks, because the materials and construction practices represent the worst case of leaking and stress corrosion cracking.

\subsubsection{Tank 16 Data Analysis}

Tank 16 was a Type II waste tank that was taken out of service. It was placed in service in 1959 and soon thereafter, 2 years, 175 leaksites in the tank wall were identified through visual examination. After removal of $70 \%$ of the leaked waste in the annulus, waste removal from the interior of the primary vessel was completed in 1980. Extensive inspections performed since 1972 indicated that the primary vessel wall has 300-350 leak sites. Of these 300 sites, 13 cracks from a single weldment region were accurately sized. ${ }^{9}$ These cracks were a representative sample of the remaining weldment regions of Tank 16.

The crack sizes were statistically analyzed. ${ }^{10}$ The possibility of crack coalescence was also considered. The crack size distribution was found to be a reasonable fit to a lognormal distribution. The lognormal distribution is a continuous probability distribution with the following probability density. 


\section{Equation 5: LogNormal Distribution ${ }^{11}$}

$$
\begin{aligned}
& f(a)=\frac{1}{a \sigma} \frac{1}{\sqrt{2 \pi}} \exp \left(-\frac{(\ln (a)-\mu)^{2}}{2 \sigma^{2}}\right) \\
& \mu=\text { Mean of }[\ln (\mathrm{a})]=0.1094 \\
& \sigma=\text { Standard deviation of }[\ln (\mathrm{a})]=0.8627 \\
& \mathrm{a}=\text { Crack length data (in.) }
\end{aligned}
$$

\subsubsection{Adjusted LogNormal Distribution}

Visual observations of cracks observed in in-service tanks have indicated a maximum crack length of 6" due to nitrate stress corrosion cracking. In addition, there are indications of a large population of 2" cracks through Type I and Type II waste tanks. It has been calculated that the maximum length of stress corrosion cracking perpendicular to a girth weld is 1.5 " from the center-line of the weld. ${ }^{5}$ This indicates that the residual stress is sufficient to provide the stress intensity for a stress corrosion crack of a total length of 3 inches. This is limited to stress corrosion cracking initiating from a single butt girth weld. In addition the residual stress analysis was done only for a Type II high level waste tank configuration.

For purposes of this study, a 6 inch reference flaw will be used as previously determined. ${ }^{12}$ It was calculated under the possibility of crack coalescence in Tank 16 . Because of limited visual imagery techniques to measure crack length, the worst case scenario of one crack being visible only in 4 sections is considered.

The lognormal distribution was adjusted to indicate a mean crack length of 2" and a 95\% cumulative distribution function of $95 \%$ for crack lengths of 6 ". This was equivalent to a $\mu$ of 0.6931 and a $\sigma$ of 0.6999 . The probability density functions of Tank 16 and adjusted data are shown in Figure 1. The cumulative density function of tank 16 and adjusted data are shown in Figure 2.

It is seen from the probability and cumulative density functions that the adjusted density function was a more conservative approach. The effects of chemistry control in the residual stress field is considered ineffective. In addition, a crack growth to a reference flaw size of 6" is allowed even though that is out of the residual stress field. Outside of the 6" reference flaw size, crack growth was not considered to be due to nitrate stress corrosion cracking, although the nitrate SCC is nevertheless applied in considering its growth. 


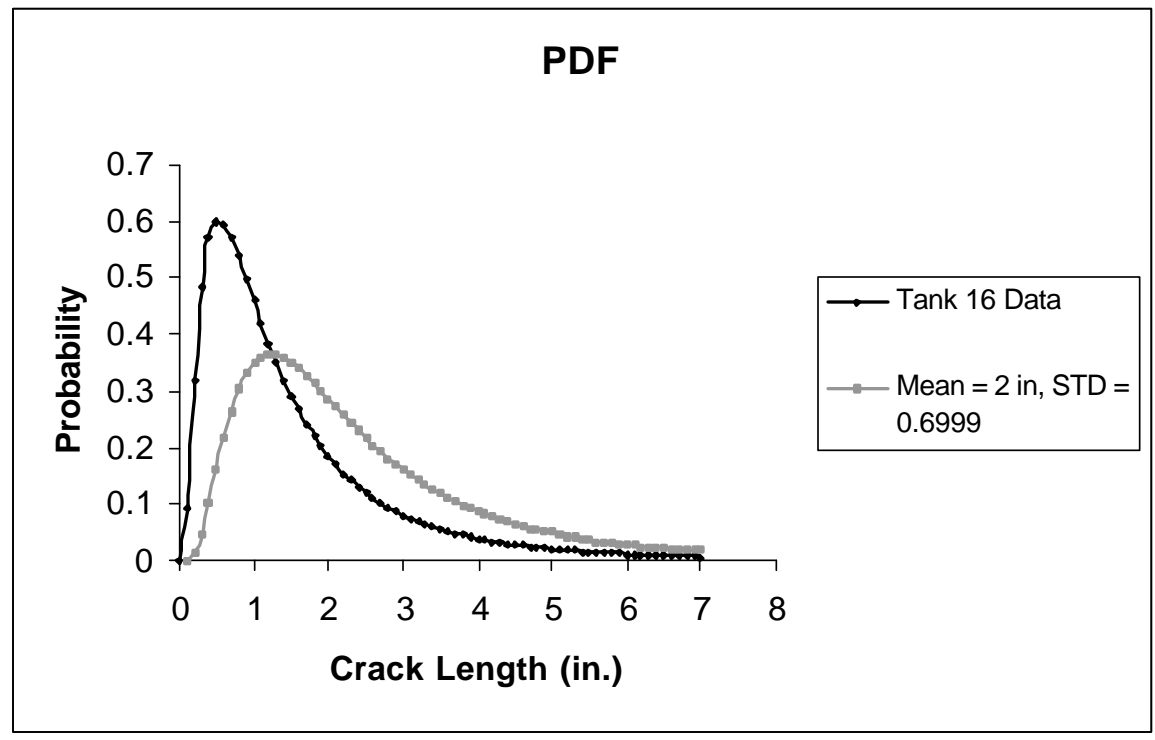

Figure 5: Probability Density Function of Tank 16 Crack Length Data and Adjusted Data to Consequent Visual Inspections.

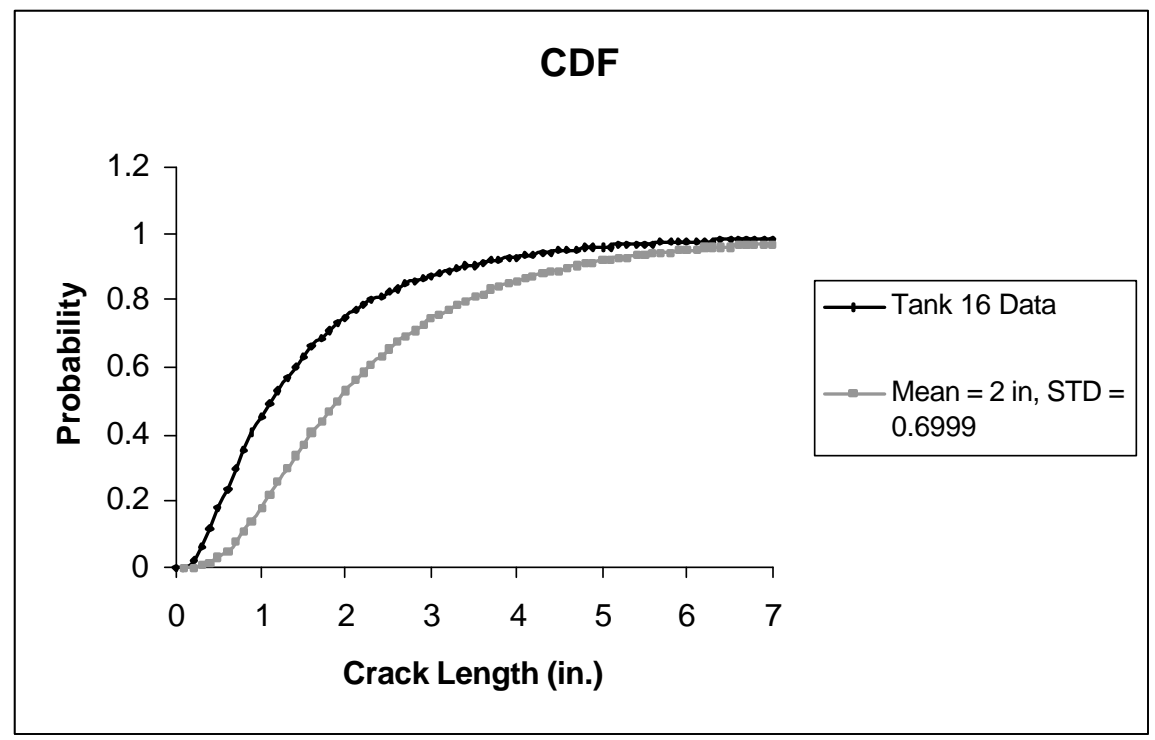

Figure 6: Cumulative Density Function of Tank 16 Crack Length Data and Adjusted Data to Consequent Visual Inspections.

\subsubsection{Instability Flaw Size}

The stability of through-wall flaws in the primary tank of Type 1 waste tanks has been previously reported. ${ }^{13}$ The J-integral fracture methodology was used to evaluate flaw stability. The flaw stability analysis was done for various fill heights and various specific gravities of waste. A material J-value of $450 \mathrm{~kJ} / \mathrm{m}^{2}$ was used as the material property input This is the lower bound fracture property as determined by the material testing program interim results. The results were shown in terms of fill-height and flaw size as a function of specific gravity. 
The instability flaw size is a function of liquid specific gravity, fill height, and stress state at the location of the flaw. The flaw instability lengths for Type I tanks under normal operating conditions is shown in Figure 7, as reproduced from Reference 13. The curves shown are for calculations made at the highest stress state of the Type I waste tanks. The instability flaw sizes in Figure 7 were interpolated using an exponential regression (shown in Figure 8) to determine the flaw stability size for $100 \%$ fill height for a specific gravity of 1.7 . Using the exponential regression, the instability flaw size at $100 \%$ fill was determined to be approximately 18 inches for a liquid specific gravity 1.7 respectively.

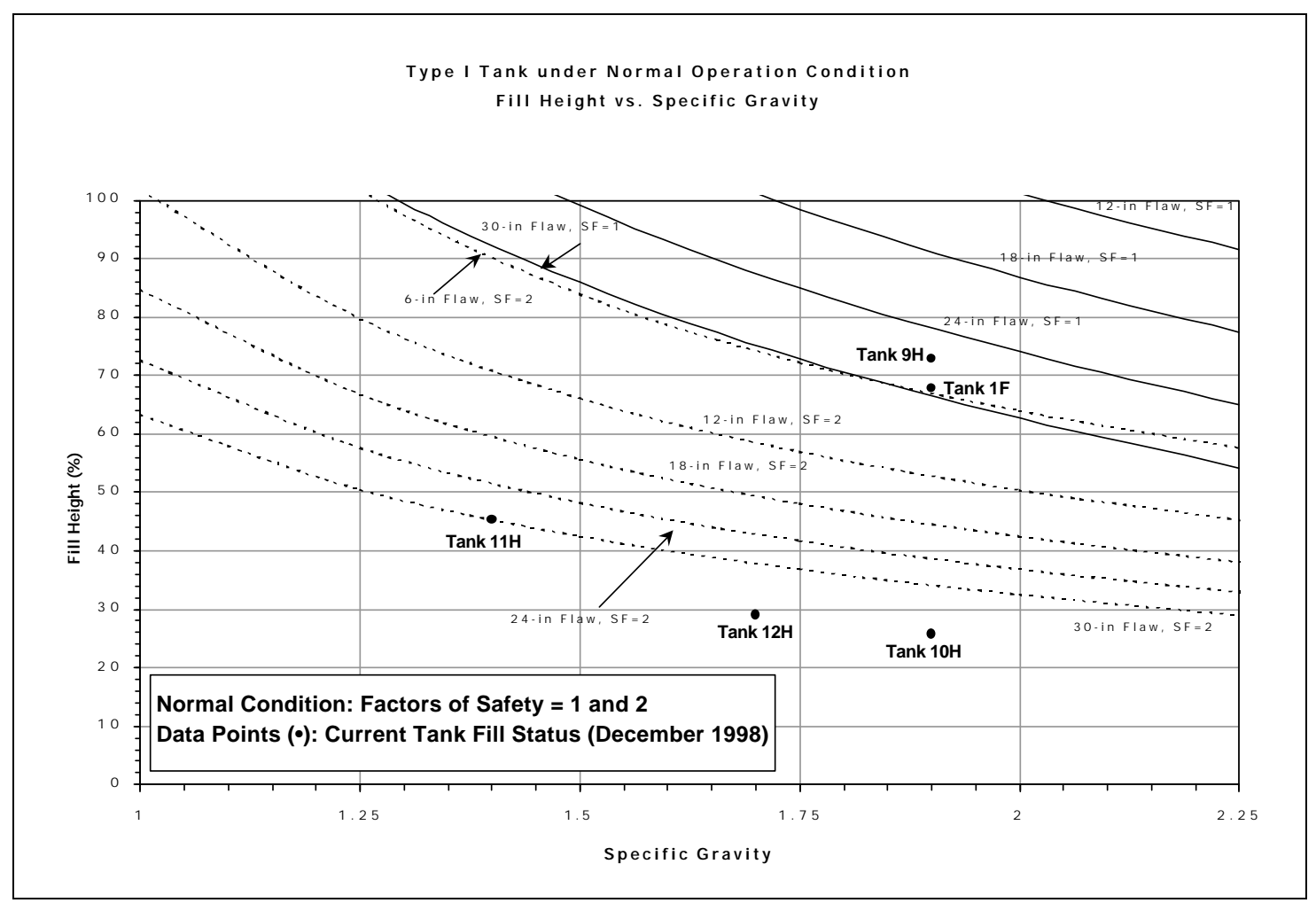

Figure 7: Flaw Instability Lengths $(\mathrm{SF}=1)$ and Fill Limits $(\mathrm{SF}=2)$ for Type I Tanks under Normal Operating Conditions. (Reproduced from Reference 13)- 


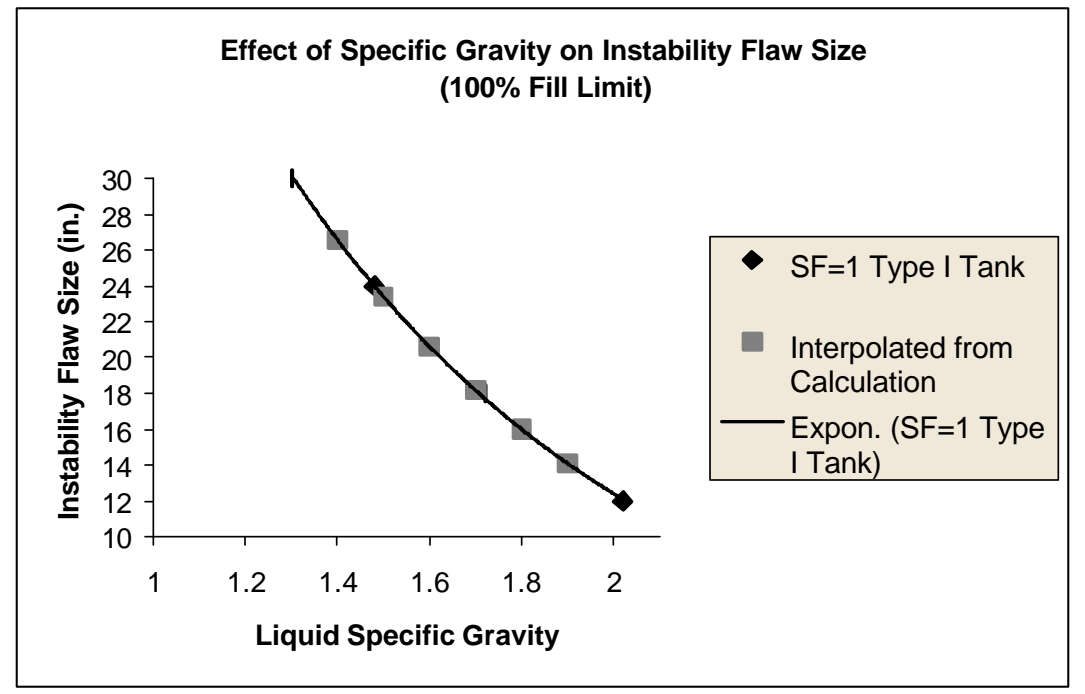

\section{Figure 8: Exponential Regression Analysis of Effect of Specific Gravity on Instability Flaw Size of Type I Waste Tanks at the Highest Stress Location.}

A stress evaluation of Type I and Type II tanks has previously been done by Structural Mechanics. ${ }^{14,15}$ The calculation evaluated the effects of normal operating and postulated seismic conditions on the structural components of an unflawed tanks. The significant loading considered in the analysis were dead weight, annulus pressure, hydrostatic pressure, relative thermal expansion between the steel tank and concrete vault, hydrodynamic pressure and inertial forces produced by the postulated seismic event. The analysis showed that seismic loads were the controlling loads. The tank allowable fill limits were calculated using ASME Section VIII, Division 2 criteria. The results are shown in Table 1. These are assumed to be the operational fill limits used for an unflawed tank in service.

Table 1: Allowable Tank Fill Limits for Type I and Type II Tanks. (Reproduced from References 14 and 15)*

\section{Tank Type $\quad$ Fill Height $\quad \underline{\text { Total Fill Height }}$}

Type I Tank Fill Limit 259 in. 276 in.

Type II Tank Fill Limit 292 in. $\quad 306$ in.

* The tank fill heights are calculated for a specific gravity of 1.7 using linear interpolation between fill heights calculated for specific gravities of 1.6 and 1.8 in References 13 and 14.

The input parameters for failure frequency calculations are shown in Table 2. The instability flaw sizes used were calculated for the bounding condition of the maximum fill height of $100 \%$. However, the allowable tank fill limits below that according to Division 2 allowables as previously mentioned. The failure frequency calculations will therefore have inherent conservatism induced by the instability flaw size component. 
Table 2: Parameters and Conditions used for Probabilistic Risk Methodology

\begin{tabular}{|c|c|}
\hline Parameter & Input Value \\
\hline Specific Gravity & 1.7 \\
\hline Maximum Fill Height (\%) & 100 \\
\hline $\begin{array}{c}\text { Maximum Allowable Fill Height } \\
\text { (From References 14 and 15) }\end{array}$ & $\underline{\text { Type I }-93.8 \%}$ \\
\hline Type II $-95.4 \%$ \\
\hline Safety Factor & 1 \\
\hline Load & Normal Operation \\
\hline Instability Flaw Size (in.) & $\mathbf{1 8 ~ i n .}$ \\
\hline
\end{tabular}

\subsection{Probability of Leak Non-Detection $\left(P_{L N D}\right)$}

The probability of leak non-detection will rely on the reliability of leak detection systems in the annular spaces of the tanks and on the ability to respond to them with a stress corrosion crack mitigating response plan. The probability calculated will utilize previously published failure rate data of these leak detection systems and also consider human factors.

Leak detection is an integral part of the failure frequency determination of the high level waste tanks. The importance of leak detection is founded upon the leak-before-break methodology (LBB). In addition, leak detection systems are in place to detect existence of leakage's from flaws in Type I and II tanks. The major assumption is that once a leak is detected, there are possible effective crack growth remediation techniques (including chemistry control) in place. Credit is taken for these possible responses in that a stress corrosion crack, once detected, will be mitigated and not be allowed to grow to instability. The probability of non-detection assumes leak detection systems will detect leakage through a stress-corrosion crack before the flaw is able to grow to instability. The conductivity probe system is the only leak detection system considered in this analysis. The visual inspection can also detect leakage's in the annular space on leaking cracks. The inspections have not been credited since they may be performed only once annually, or once in two years.

\subsubsection{Leakage Characterization Including Leak-Before-Break Methodology}

The concept of leak-before-break (LBB) methodology implies that any crack or defect which develops in the waste tank will grow to a through-wall configuration, and can be detectable by leak detection systems before reaching a size that would significantly reduce safety margins to large break failure.

In essence, the probability of leak non-detection was determined to be equivalent to the failure of instrumentation in conjunction with human factors. In addition, it is assumed that crack growth during the time taken to respond to the leak after leak detection will be short enough to not allow crack growth to instability. The response time to a triggered leak detection system is integral to ensure minimal leakage from any stress corrosion crack. 
The leak-before-break methodology has been adapted to the high level waste tanks. The range of leak rates and flow velocity through postulated through-wall cracks in the primary steel liners of Type I and II High Level Waste (HLW) tanks have been determined by PE\&CD, Structural Mechanics. ${ }^{16}$ Assuming a six inch through-wall crack in the worst location of supernate, sludge or salt tanks, with a viscosity between 5-10 centipoise, the resulting leak rates were calculated to be less than $0.34 \mathrm{in}^{3} / \mathrm{sec}(0.09 \mathrm{gpm})$. The maximum velocity of fluid exiting the crack was calculated to be less than $19 \mathrm{in.} / \mathrm{sec}(1.1 \mathrm{mph})$. The maximum leak rates for dilute waste from a six inch crack were calculated to be less than $1.4 \mathrm{in}^{3} / \mathrm{sec}(0.36 \mathrm{gpm})$ with the maximum fluid velocity less than $70 \mathrm{in} / \mathrm{sec}(4 \mathrm{mph})$. Salt deposit formation due to evaporation of waste was omitted for purposes of these leak rate calculations. It may be rationalized that leak rates will be minimized by salt deposits that form around stress corrosion crack thereby "plugging" the leak source. However, flaw growth to instability would result in large crack mouth openings and pluggage would not be expected. Service experience at SRS shows detectable leakage's from cracks approximately one inch in length.

An evaluation was done to postulate accident scenarios of waste leakage into the annulus. It was demonstrated that waste will seep or stream slowly (rather than spray) from a flaw down the side of the primary wall regardless of the waste fill level, specific gravity, or viscosity. ${ }^{17}$ The lack of spraying was determined to be primarily due to four factors: (1) relatively low head pressure due to the liquid level, (2) tortuous geometry of the stress corrosion cracks, (3) physical characteristics of the waste (i.e., viscosity), and (4) salt deposit formation due to evaporation of the waste.

\subsubsection{Conductivity Probe Leak Detection Systems}

The annulus of each of the Type I and II waste tanks is equipped with at least two singlepoint conductivity probes for leak detection. These probes are located in the bottom of the annulus and are on opposite sides of the tank. These probes are safety class instrumentation and are alarmed to a control room that is continuousl manned.

Leak detection for the primary liner of double shell tanks consists of instrumented and visual surveillance for liquid in the annular space between the primary secondary liners. Conductivity probes, supplemented by dip tubes, are installed in each tank annulus to provide early warning or liquid accumulation in the annulus. For each tank, at least two stationary conductivity probes are provided for determining the presence of liquid in the annulus. Three of the probes are single point devices, and the fourth is a multi-point device that can approximate the liquid level in the annulus. Evidence of the leakage into an annulus is signaled to the tank farm control room. The leak detection systems ensure that a leakage can be detected and the waste can be returned to primary storage.

\subsubsection{Conductivity Probe Surveillance}

Surveillance procedure SW10.6-SR-3.3.2, Rev. 4 provides the detailed operating and test instructions for normal and infrequent surveillance of the F Tank Farm conductivity probes. ${ }^{18}$ This reference is made for surveillance of F Tank Farm conductivity probes, but is assumed to be similar for installed probes in all Type I and II high level waste tanks for purposes of this study. 
The conductivity probes are Safety Class (SC) equipment as per Technical Safety Requirements (TSR). The annulus conductivity probes are installed on the floor of the annulus between the primary tank wall and the ventilation duct. When salt is in the annulus, the probe is typically installed on the salt layer or just above the salt layer. The installation process ensures that the probe satisfies the TSR within Authorization Basis (AB) limits. The surveillance procedure indicates that the conductivity probe be installed less than 23 inches from the annulus floor for Type I and II tanks. If there are salt deposits on the annulus floor, the conductivity probes will be installed on top of the deposits. However, the probes will be no higher than the top of the ventilation duct in the vicinity of the probe. The surveillance probes are tested for functionality monthly and the failure to meet the acceptance criteria could result in a violation of the TSR (LCO 3.3.2). At any given time, at least one of the two probes are required to remain operable. If both probes are not operable, an equivalent means of annular leak detection must be instituted.

The conductivity probes are triggered when the amount of liquid waste reaches a height of $0.25 \mathrm{in}$. in the annular space. The annular space is $30 \mathrm{in}$. wide, translating to a holding capacity of approximately 366 gallons of liquid waste per inch of height in the annular space. A leakage of 91.5 gallons is calculated to be necessary to trigger the conductivity probe under several assumptions: (1) the liquid waste in the annulus is at an equal height throughout the annular space, (2) each of the conductivity probes will be triggered simultaneously at a waste fill of 91.5 gallons. Utilizing the previously mentioned leak rates at their specific conditions, it was calculated that the conductivity probe will be triggered in less than 16.9 hours for supernate, salt or sludge tanks, and less than 4.2 hours for dilute waste tanks. The limitation was again the omission of salt deposit formation around the leaking crack.

$$
\left(366^{g} / \text { in. }\right)(0.25 \text { in. })=91.5 \text { gallons }
$$

Supernate, Sludge, and Salt: $\frac{(91.5 \text { gallons })}{(0.09 \mathrm{~g} / \mathrm{min} .)}=16.9$ hours

Dilute Waste: $\frac{(91.5 \text { gallons })}{(0.36 \mathrm{~g} / \mathrm{min} .)}=4.2$ hours

The surveillance procedure also enumerates testing of the functionality of annular conductivity probes. The conductivity probes are alarmed and tested for functionality once a month. Each probe deemed to be non-operable has a finite time period within which it must be rendered functional.

\subsubsection{Conductivity Probe Failure Rate}

A compilation of useful component failure rate data gleaned from published literature and accessible databases has been previously published. ${ }^{19}$ The failure rate of a conductance sensor/detector from Reference 16 is $6.24 \times 10^{-6} / \mathrm{hr}$. This translates to a failure rate of $4.5 \times 10^{-3}$ per month, assuming 30 days as the average number of days for each month. A monthly failure 
rate is used to reflect the one month intervals between functionality tests of the conductivity probes.

This probability of failure of the conductivity probe will be reset after each inspection. Only one conductivity probes is required by Technical Safety Requirements to remain operable at all times. However, for purposes of this calculation, it is assumed that there are two operable conductivity probes or equivalent means of annular space leak detection. Therefore, there is an active redundancy, as shown in Figure 9. Figure 9 indicates the use of two conductivity probes, but either may be substituted for by an alternate but equivalent means of leak detection.

An active redundancy indicates there is an independent leak detection system for each of the various conductivity probes. Therefore, satisfactory operation of the conductivity probe is assumed to occur if only one of two conductivity probes are functioning. It is assumed that the waste will eventually be equally dispersed throughout the annular space well before a crack may approach instability. Therefore, the position of the leak on the tank wall is assumed to not effect the triggering of the conductivity probe. Each conductivity probe is assumed to cover the entire annular space for liquid waste detection. Accrediting the active redundancy between two conductivity probes yields a failure rate of $2 \times 10^{-5}$. The reliability of the system is equal to the probability of each of the conductivity probes functioning as shown in Figure 9. The failure rate was calculated as follows where $\mathrm{R}$ is reliability of the conductivity probe and the failure rate of the conductivity probe is defined to be $1-R$. $R_{1}$ is the reliability of conductivity probe 1 and $R_{2}$ is the reliability of conductivity probe 2 , both of which are assumed to cover the entire annular space.

Equation 6: Conductivity Probe Leak Detection Failure.

$$
\begin{aligned}
& R_{\text {system }}=\left(R_{1}+R_{2}\right)=R_{1}+R_{2}-R_{1} R_{2} \\
& R_{\text {system }}=\left(R_{1}+R_{2}\right)=2\left(1-4.5 \times 10^{-3}\right)-\left(1-4.5 \times 10^{-3}\right)^{2} \\
& R_{\text {system }}=\left(R_{1}+R_{2}\right)=0.99998 \\
& P_{\text {ProbeFailure }}=2 \times 10^{-5}
\end{aligned}
$$

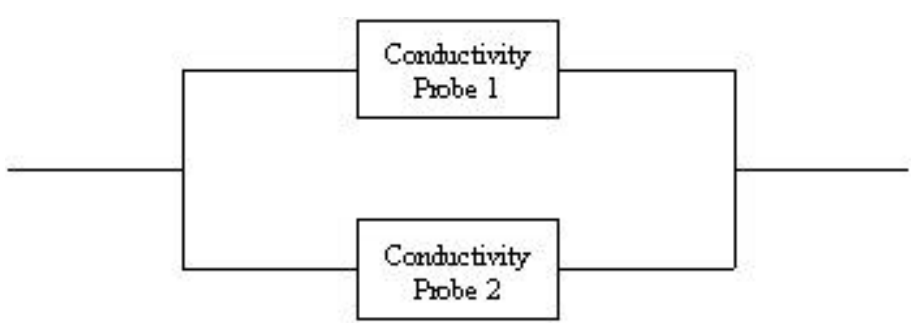

Figure 9: Active Dual Redundant Conductivity Probe System.

\subsubsection{Probability of Leak Non-Detection $\left(\mathbf{P}_{\mathrm{LND}}\right)$ Calculation}

The probability of leak non-detection was determined to be the failure of the conductivity probe to detect leakage into the annulus. Leak non-detection due to operator inattentiveness was 
also considered. The extended period of time required for a crack to grow to instability indicated repeated shift changes and many independent verifications of the conductivity probe alarm. Therefore, human error was disregarded as a possible component of leak non detection. The total probability of leak non-detection is the probability of the failure of a conductivity probe, or equivalent means of leak-detection to detect a crack.

\section{Equation 7: Probability of Leak Non-Detection}

$$
\begin{aligned}
& P_{L N D}=P_{\text {ProbeFailure }} \\
& P_{L N D}=2 \times 10^{-5}
\end{aligned}
$$

\section{ESTIMATION OF LARGE BREAK FREQUENCY UNDER NORMAL OPERATION}

The large break frequency was calculated using Equation 4. The large break failure frequency was calculated for a specific gravity of 1.7 to provide a conservative bounding liquid specific gravity and instability flaw size. This translates to a conservative failure frequency.

From Figure 8, it was determined by exponential interpolation that the instability flaw size for a liquid specific gravity of 1.7 at 100\% fill for Type I tanks was 18 inches. Utilizing 18 in. as the instability flaw size and 2.5 in/year crack growth due to nitrate stress-corrosion cracking, a currently existing 15.5 in. crack is necessary for crack growth to instability within one year. This probability was calculated to be $5.1 \times 10^{-4}$ using the adjusted lognormal probability distribution function. The failure frequency was calculated to be $1.02 \times 10^{-8} \mathrm{LB} / \mathrm{year}$ as follows:

$$
\begin{gathered}
\mathbf{P}_{\mathrm{FF}}=\mathbf{P}_{\mathrm{UIW}} \\
\mathbf{P}_{\mathrm{UIW}}=\mathbf{P}_{\mathrm{C}} \cdot \mathbf{P}_{\mathrm{ND}} \cdot \mathbf{P}_{\mathrm{CG}} \cdot \mathbf{P}_{\mathrm{LND}} \\
\mathbf{P}_{\text {UIW }}=\mathbf{1} \cdot \mathbf{1} \cdot\left(\mathbf{5 . 1} \times \mathbf{1 0}^{-4}\right) \cdot\left(2 \times 10^{-5}\right) \\
\mathbf{P}_{\mathrm{FF}}=\mathbf{P}_{\mathrm{UIW}} 1.02 \times 10^{-8} \mathrm{LB} / \text { year }
\end{gathered}
$$

The instability flaw size was calculated at the highest stress location of a $100 \%$ fill Type I waste tank. This translates to the large break failure frequency of beyond extremely unlikely. $\left(<10^{-6}\right.$ magnitude). However, the fill limits are governed by Division 2 allowables as previously mentioned.

\section{DISCUSSION}

The annual large break frequency was calculated was valid only for a specific set of parameters, as listed in the following:

1. Nitrate stress corrosion cracking was the only degradation mechanism considered significant that could lead to a large break failure.

2. The crack growth rate due to stress corrosion cracking was calculated in laboratory experiments and is applied to SCC in waste tanks. 
3. It was assumed that the crack length around the single butt girth weld was limited to 6 inches in the $95^{\text {th }}$ percentile cumulatively. Residual stress relief was assumed to have occurred at crack lengths greater than 6 inches.

4. Chemistry control effects in the residual stress field are not considered. It is assumed that the initiation of stress corrosion cracks in the residual stress field is not possible if the chemistry controls are effective. However, it has been previously mentioned that bulk solution chemistry does not affect stress corrosion crack growth. Localized chemistry in the field of the crack tip controls the aggressive environment required for stress-corrosion cracking as well as mitigating crack growth within residual stress field.

5. Crack growth remediation response plans once the crack has been located are considered effective. The failure of crack growth remediation is not considered.

6. Human error was disregarded.

The failure frequency analysis done generically for Type I and II high level waste tanks without analysis of specific service history for each tank, or properties for each type of tank. The instability flaw sizes that have been calculated for Type I tanks have been used for Type II tank configurations for purposes of this calculation. It will be more complete to develop a family of probabilities that will include various fill heights, specific gravities, and consequently various instability flaw sizes. This would be one component of tank specific failure frequency analysis. In addition, a tank specific instability flaw size should be determined to ensure precision of failure frequency. The failure frequency is highly sensitive to instability flaw size and crack growth distribution.

The sensitivity of the failure frequency of large break failure to the instability flaw size was calculated. Figure 10 shows the failure frequency as a function of instability flaw size. It is seen that failure frequency becomes more affected with decreasing instability flaw size. At higher instability flaw sizes, the failure frequency is less affected but the event of large break failure goes beyond extremely unlikely. The calculations were done for existing flaw sizes of 9.5 in. to 25 inches which translates to instability crack lengths of 12 in to 27.5 in. assuming the growth rate of stress corrosion cracking in waste tanks to be 2.5 in./year as previously noted.

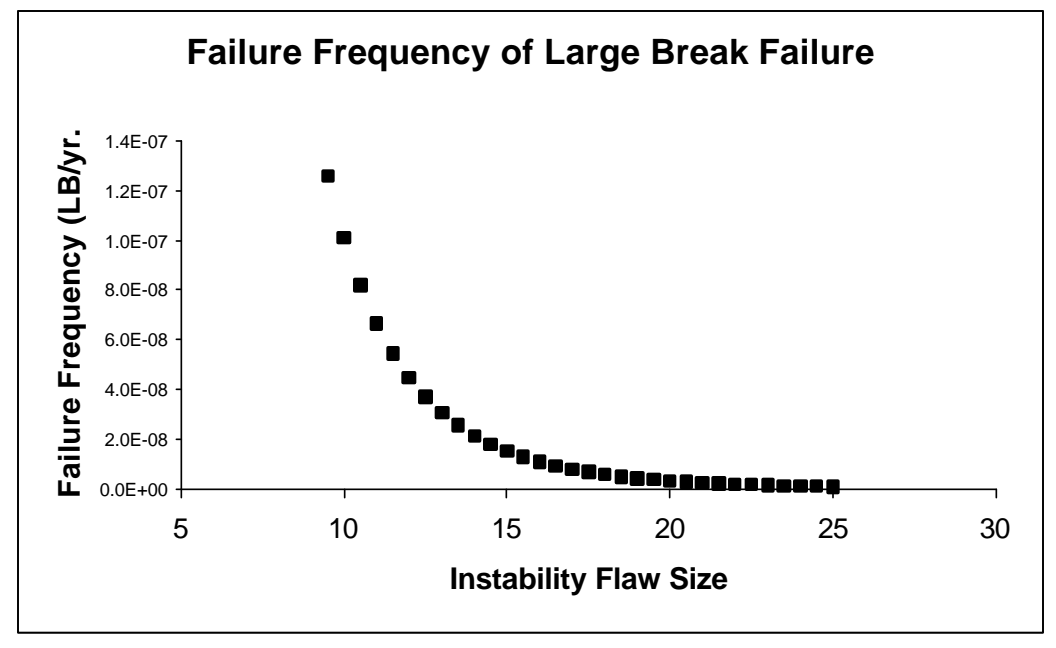

Figure 10: Sensitivity of Failure Frequency of Large Break Failure to Instability Flaw Size. 
A tank-specific failure frequency would include the tank fill height and liquid specific gravity to calculate instability flaw sizes. The 18in. instability flaw size is a bounding condition for the present Type I and Type II tank configurations.. 


\section{REFERENCES}

${ }^{1}$ Daugherty, W. L., “Reactor Materials Program Process Water Piping Large Break Frequency (U),” WSRC-RP-9097, March 1990.

${ }^{2}$ Costas, L. P., Holzworth, M. L., Rion, W.C., "Stress Corrosion Cracking of Carbon Steels in Simulated Waste Solutions," DP-1023, June 1966.

${ }^{3}$ Poe, W. L., “Leakage from Waste Tank 16: Amount, Fate, and Impact,” DP-1358, November 1974.

${ }^{4}$ Dong, P., Zhang, J., Hong, J. K., Brust, F. W., “Task 1: Residual Stresses and Stress Intensity Factors for Single Butt Welds," Final Report No. G003824-01, Battelle Memorial Institute, September 1999.

${ }^{5}$ Zapp, P. E., Lam, P-S., "Preliminary Evaluation of Tank 15 Vapor Space Cracking," WSRC-TR-2000-187, June 2000.

${ }^{6}$ Mealing, J. M., Moore, C. J., Robbins, R. R., Waltz, R. S., West, W. R., “Annual Radioactive Waste Tank Inspection Program - 1999 (U)," WSRC-TR-2000-00067, May 2000.

${ }^{7}$ Sindelar, R. L., Wiersma, B. J., "SRS High Level Waste Tank and Piping Systems - Structural Integrity Program and Topical Report (U),"WSRC-TR-95-0076, Rev. 0, June 1995.

${ }^{8}$ Donovan, J. A., "Materials Aspects of SRP Waste Storage-Corrosion and Mechanical Failure,” DP-1476, November 1977.

${ }^{9}$ Wheeler, R. E., to Ondrejcin, R. S., "Waste Tank Weld Crack Length,” October 1, 1979.

${ }^{10}$ Harris, S. P., to Sindelar, R. L., Wiersma, B. J., “Analysis of Waste Tank 16 Crack Data (U),” SRT-ASG-930094, December 27, 1993.

${ }^{11}$ Vardeman, S. J., Statistics for Engineering Problem Solving. PWS Publishing Company, 1994. p.220.

${ }^{12}$ Wiersma, B. J., Sindelar, R. L., "Reference Flaw Size for Structural and Fracture Analysis of Types I and II Waste Tanks (U),” WSRC-TR-94-041, January 1994.

${ }^{13}$ Lam, P-S., Sindelar, R. L., "Preliminary Report: Type I Waste Tank Flaw Stability Analysis and Tank Fill Limits (U),"WSRC-TR-99-00163, May 1999.

${ }^{14}$ Chaudhari, V. N., “Stress Evaluation of Type I Tanks (U),” T-CLC-H-00395, March 1999.

${ }^{15}$ Chaudhari, V. N., “Stress Evaluation of Type II Tanks (U),” T-CLC-H-00378, August 1999.

${ }^{16}$ Mertz, G. E., "Potential Leak Rates Through Cracks in HLW Tanks,” T-CLC-G-00135 Rev. 0, December 1999.

${ }^{17}$ Wiersma, B. J., "Evaluation of Potential Spraying Incident in High Level Waste Tanks (U)," WSRC-TR-9900441, November 1999.

18 “F Tank Farm Annulus Conductivity Probe Surveillance Requirements,” SW10.6-SR-3.3.2, Rev. 4, 5/16/00.

${ }^{19}$ Dexter, A. H., Perkins, W. C., "Component Failure Rate Data with Potential Applicability to a Nuclear Fuel Reprocessing Plant,” DP-1633, July 1982. 


\section{REPORT WSRC-TR-2001-00022}

\section{DISTRIBUTION}

\section{SAVANNAH RIVER SITE}

C. R. Wolfe, 773-A

N. C. Iyer, 773-A

R. L. Sindelar, 773-41A

G. T. Chandler, 773-A

P. S. Lam, 773-41A

A. J. Duncan, 773-41A

K. H. Subramanian, 773-41A

Site Records, 773-52A
T. J. Lex, 703-H

W. I. Lewis, III 703-H

T. M. Monahon, 703-H

B. L. Lewis, 703-H

D. J. Martin, 703-H

B. J. Wiersma, 773-A 